\title{
PERILAKU PROSOSIAL SISWA SMP DI ERA REVOLUSI INDUSTRI 4.0 (KOLABORASI GURU DAN KONSELOR)
}

\author{
Nila Zaimatus Septiana \\ Institut Agama Islam Negeri Kediri \\ nila.zaima@gmail.com
}

\begin{abstract}
Industry Revolution 4.0 (IR-4) is a disrupted era characterized by a change in the old system with a new technology-based system in the form of loT (Internet of Things). In the world of education the existence of a new system has an impact on changes in mindset, attitudes and behavior of students. Students who have a high dependence on technology tend to be indifferent to the environment. This results in a weak pattern of direct interaction between students and students' prosocial behavior. Prosocial behavior is an action that can provide benefits for both yourself and others in the social environment. This study aims to describe how prosocial behavior of students in the industrial revolution era 4.0 and collaborative efforts of teachers and counselors in improving students' prosocial behavior in schools. The method used in this study is descriptive qualitative. The subjects of this study were teachers and counselors who were selected according to predetermined criteria. Then the data analysis technique uses narrative techniques. The results showed that the prosocial behavior of students in the industrial revolution era 4.0 was decreasing, so that direction and guidance were needed from both teachers and counselors to restore the nature of individuals as social beings. To improve the prosocial behavior of students both teachers and counselors design various collaborative activities that are beneficial to the social life of students at school.
\end{abstract}

Key Words

prosocial behavior, industry revolution 4.0 , teacher and counselor's collaboration

Cara mengutip: Septiana, Nila Zaimatus (2019) Perilaku Prososial Siswa SMP di Era Revolusi Industri 4.0 (Kolaborasi Guru dan Konselor). Nusantara of Research. 6(1), 1-15

\section{PENDAHULUAN}

Revolusi industri 4.0 merupakan era disrupsi yang ditandai dengan pergantian sistem lama dengan sistem baru berbasis teknologi yang berupa loT (Internet of Things). IoT merupakan suatu konsep dimana objek tertentu memiliki kemampuan untuk mentransfer data melewati jaringan tanpa memerlukan adanya interaksi dari manusia ke manusia lain atau dari manusia ke perangkat komputer. Adapun pemanfaatan loT tersebut pertama kali dilakukan oleh Jerman dan Jerman pula yang mengglobalkan istilah industri 4.0 sejak tahun 90-an.

Ciri-ciri revolusi industri 4.0 yang dapat diamati saat ini yakni kehidupan masyarakat mulai bertumpu pada cyber-physical system (CPS). CPS merupakan integrasi antara komputasi, jaringan dan aktifitas fisik dimana aktifitas fisik tersebut dapat berdampak pada proses komputasi dan sebaliknya. CPS menggabungkan proses fisik yang dinamis dengan jaringan dan komputer sehingga menyediakan suatu bentuk yang abstrak, model dan desain serta teknik analisis yang mengintegrasikan keseluruhan hal tersebut. Dengan adanya CPS manusia dituntut untuk beradaptasi dengan cepat.

Gagasan Industri 4.0 pertama kali dicetuskan oleh pemerintah Jerman sebagai bagian dari strategi teknologi tinggi untuk mempromosikan industri komputerisasi dan 
manufakturnya. Industry 4.0 adalah inisiatif strategis pemerintah Jerman yang secara tradisional sangat mendukung pengembangan sektor industri. Dalam hal ini, Industry 4.0 dapat dilihat juga sebagai tindakan untuk mempertahankan posisi Jerman sebagai salah satu negara paling berpengaruh dalam permesinan dan manufaktur otomotif. Konsep dasar pertama kali dipresentasikan di pameran Hannover pada tahun 2011. Sejak diperkenalkan, Industry 4.0 di Jerman menjadi topik diskusi umum dalam komunitas penelitian, akademik, dan industri di berbagai kesempatan. Gagasan utamanya adalah memanfaatkan potensi teknologi dan konsep baru seperti ketersediaan penggunaan internet / internet of things (loT), integrasi proses teknis dan proses bisnis di perusahaan-perusahaan, pemetaan digital dan virtualisasi dunia nyata, 'Pabrik' yang cerdas termasuk alat produksi industri yang 'pintar' dan produkproduk 'pintar' (Andreja: 2017).

Andi \& Sinan (2017), juga menggambarkan tentang perkembangan revolusi industri 4.0 yang telah meluas di seluruh Eropa dan telah diadopsi di Asia, terutama di Cina. Di Amerika dan dunia istilah 'internet of things', internet industri 'atau' internet adalah segalanya' diterapkan sebagai alternatif. Poin utama dari konsep ini adalah metode pembuatan dan produksi tradisional yang sedang mengalami transformasi ke digital. Adopsi umum yang dilakukan oleh industri manufaktur teknologi informasi dan komunikasi (TIK) secara progresif mengurangi batasan antara dunia nyata dan dunia virtual, seta menciptakan sistem produksi baru, khususnya, sistem produksi cyberphysical (CPS).

CPS merupakan jaringan online dari "mesin sosial" yang dirancang sesuai dengan jaringan sosial. Secara khusus, Teknologi informasi akan dihubungan dengan bagian mekanik dan elektronik yang kemudian berinteraksi satu sama lain melalui jaringan. Dapat dikatakan bahwa teknologi identifikasi frekuensi radio (RFID), yang telah digunakan sejak 1999, adalah bentuk awal dari teknologi ini. CPS tidak hanya mesin jaringan yang saling berhubungan satu sama lain, sistem ini juga menciptakan jaringan mesin, properti, sistem teknologi informasi dan komunikasi, produk pintar dan individu yang cerdas di seluruh rantai nilai dan siklus hidup sebagai produk lengkap. Dengan demikian, sensor dan elemen kontrol tersebut memungkinkan menghubungkan mesin ke pabrik, armada, jaringan, dan manusia.

Revolusi industri 4.0 menunjukkan perkembangan yang sangat signifikan dalam bidang teknologi dan pemerolehan informasi, hal ini dapat dilihat dari perkembangan revolusi industri mulai dari yang pertama. Adapun tahapan dalam perkembangan sistem manufaktur industri dari proses manual hingga konsep Industry 4.0 dapat dilihat pada Gambar 1.1 berikut:

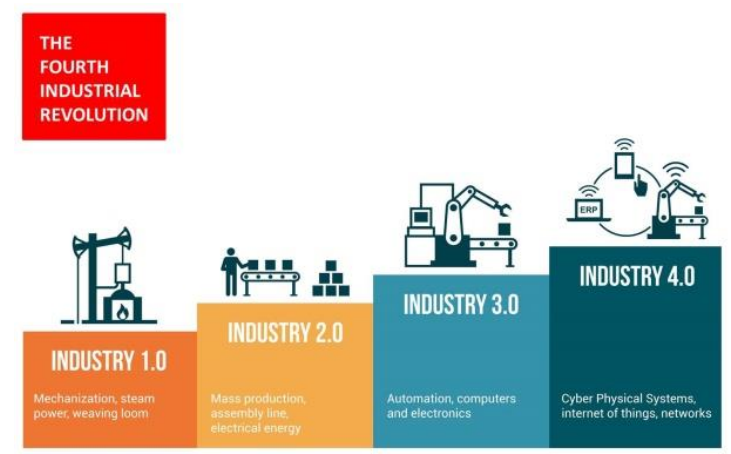

Gambar 1.1 Tahapan revolusi industri (sumber: google) 
Revolusi industri pertama (FIR) dimulai dengan mekanisasi dan pembangkit tenaga mekanik pada tahun 1800-an. Hal ini membawa transisi dari pekerjaan manual ke proses manufaktur pertama dan sebagian besar dilakukan pada industri tekstil. Peningkatan kualitas hidup adalah pendorong utama adanya perubahan.

Revolusi industri kedua (SIR) dipicu oleh proses elektrifikasi yang memungkinkan industrialisasi dan produksi massal. Hal yang sering disebutkan dalam konteks ini adalah kutipan dari Henry Ford, yang mengatakan tentang mobil T-Model Ford "Anda dapat memiliki warna apa pun asalkan warnanya hitam." Kutipan ini menangkap dengan baik pengenalan produksi massal tetapi tanpa kemungkinan kustomisasi produk.

Revolusi industri ketiga (TIR), dimulai pada tahun 1969 dengan pengembangan Jaringan Badan Proyek Penelitian Lanjutan (Advanced Research Projects Agency Networkl ARPANET), yang merupakan jaringan packet switching awal dan jaringan pertama yang mengimplementasikan paket protokol TCP / IP. Hal tersebut memicu perkembangan internet di era informasi. Hampir sama dengan revolusi sebelumnya, revolusi industri ketiga didorong terutama oleh kemajuan teknologi di bidang manufaktur, distribusi dan faktor energi. Revolusi industri ketiga bersifat global, tetapi juga bersifat lokal, sehingga menimbulkan istilah 'glokal'. TIR diatur untuk mengubah cara kita bekerja, memproduksi, dan mencari kegiatan yang menyenangkan. Hal ini secara fundamental akan mengubah cara kita merencanakan dan mengelola sesuatu, sehingga dapat mengarah pada glokalisasi produksi dan penyesuaian kembali dalam bidang pekerjaan (Roberts, 2015)

Saat ini memasuki revolusi industri keempat yang dipicu oleh pengembangan Teknologi Informasi dan Komunikasi (TIK). Basis teknologinya adalah otomatisasi cerdas dari sistem cyber-physical dengan kontrol terpusat dan konektivitas canggih (keberfungsian loT/ Internet of Things). Dampak dari teknologi baru ini untuk sistem produksi industri adalah reorganisasi sistem otomatisasi hierarkis klasik untuk mengatur sendiri sistem produksi cyberphysical yang memungkinkan produksi kustom massal yang fleksibel dan fleksibilitas dalam jumlah produksi.

Dampak dari revolusi industri 4.0 di bidang industri tidak bisa diragukan lagi, hal tersebut dapat menguntungkan secara nilai materiil karena dapat dengan mudah memenuhi kebutuhan pasar yang bervariasi. Namun, disisi lain dengan penggunaan teknologi akan berdampak pula terhadap perekrutan tenaga kerja. Banyak perusahaan menggunakan sistem robotik dalam proses produksi sehingga tenaga manusia semakin tidak diperlukan lagi.

Lima tahun setelah diperkenalkan di Jerman, konsep Industry 4.0 dikenal di seluruh dunia dan telah ditransfer dari bidang aplikasi aslinya ke bidang manufaktur industri di bidang teknik dan non-teknik lainnya. Konsep yang sesuai seperti Otomotif 4.0, Logistik 4.0 dan Pendidikan 4.0 memiliki kesamaan dengan makna asli Industri 4.0 hanya penggunaan alat TIK, konektivitas yang luas serta menangkap dan menganalisis data waktu-nyata.

Dalam bidang pendidikan, baik pendidik maupun peserta didik saat ini sudah mulai beradaptasi dalam menghadapi tantangan di era revolusi industri 4.0. Istilah pendidikan 4.0 yang diadaptasi dari konsep industri 4.0, memiliki ciri khusus yang sama terutama dalam pemanfaatan teknologi dalam proses pembelajaran. Kemudahan mencari informasi, mentransfer informasi dan membuat sesuatu yang baru dengan mudah dilakukan hanya 
dengan mengkoneksikan komputer dan jaringan. Perubahan cara kerja lama dengan cara kerja baru yang serba mudah secara otomatis memicu adanya perubahan pola pikir, cara kerja dan hubungan yang harmonis antar individu atau kelompok masyarakat. Perubahan yang disikapi secara bijak akan dapat menghasilkan output yang positif namun sebaliknya, jika perubahan tersebut disikapi kurang bijak akan merugikan baik diri sendiri maupun orang lain.

Selain dampak positif, ada pula dampak negatif dari penggunaan teknologi antara lain dari aspek sosial, terganggunya proses interaksi langsung dengan orang disekitar baik teman maupun keluarga, stress akibat informasi yang muncul di media yang tidak sesuai dengan harapan, terbengkalainya tugas dan kewajiban, dan kecanduan gadget yang membuat seseorang menjadi tergantung dan tidak mandiri.

Beberapa kasus terkait dengan dampak negatif penggunaan teknologi (khususnya gadget) yang dialami oleh para remaja antara lain, artikel yang ditulis oleh Larasati (2018), mengenai perundungan di dunia maya (cyber bullying) dan kasus body shaming. Selain itu juga dari artikel yang ditulis oleh Josina (2018), terdapat kasus pelecehan di dunia maya dan juga di dunia nyata yang dilaporkan dari dua aplikasi terkemuka yakni facebook dan whatsapp

Kasus selanjutnya yakni terkait penggunaan teknologi informasi yang tidak tepat sehingga dapat mendistorsi kehidupan masyarakat Indonesia. Salah satunya dari artikel yang ditulis oleh Sukoyo (2018) mengenai penyebaran informasi hoax yang masif. Banyak individu yang mudah terpengaruh berita hoax yang ada di media. Penelitian Deepty \& Geeta (2015) mengungkap tentang masa remaja dan kaitannya konsep diri dan perilaku prososial remaja. Hasil penelitian menunjukkan ada hubungan signifikan antara perilaku prososial dan konsep diri remaja Perilaku prososial dimaksudkan untuk menciptakan empati, kooperatif, tanggungjawab sosial yang positif dan menguntungkan satu sama lain. Dengan demikian diharapkan perilaku prososial remaja tinggi shingga dapat menghindari kasus yang timbul akibat pengaruh negatif dari perkembangan teknologi khususnya media sosial.

Kasus lain yang sering dialami dan mengalami peningkatan signifikan akibat kurang bijak dalam berteknologi seperti pada artikel yang ditulis oleh Nugraha (2018), yakni kasus penghinaan dan penipuan, hal tersebut dipengaruhi oleh tingginya penggunaan internet, pengguna media sosial termasuk jual beli online. Selanjutnya artikel Miranti (2018) juga mengungkapkan terkait kasus kejahatan yang muncul yakni adanya kasus pembunuhan yang dilakukan seorang remaja ketika cintanya ditolak oleh seorang gadis yang dikenal di dunia maya.

Banyaknya kasus yang dialami oleh remaja akibat kurang bijaknya dalam menggunakan teknologi sehingga merugikan diri sendiri bahkan orang lain. Menteri Riset, Teknologi dan Pendidikan Tinggi, Mohammad Nasir, dalam artikel Puspita (2018) menyebutkan, perubahan era Revolusi Industri 4.0 harus dibarengi dengan perubahan perilaku sosial dan perilaku budaya.

Perilaku sosial merupakan perilaku yang diperuntukkan kepada orang lain. Kemudian perilaku budaya merupakan perilaku yang berkaitan dengan akal budhi dan daya manusia. Jika digabungkan perilaku sosial berbudaya yakni perilaku yang dimaksudnya untuk menjalin interaksi dengan orang lain di lingkungan sosialnya dengan menggunakan akal budi dan daya manusia. Dengan berperilaku tersebut diharapkan dapat menjalin interaksi yang saling 
menguntungkan bagi semua pihak yang berinteraksi. Perilaku menguntungkan tersebut disebut pula dengan perilaku prososial.

Perilaku prososial yakni perilaku atau tindakan yang dapat memberi keuntungan baik bagi diri sendiri maupun orang lain. Perilaku prososial sangat diperlukan dalam menghadapi era teknologi informasi dan komunikasi sebagai bentuk penyesuaian di era revolusi industri 4.0.

Perlunya perilaku prososial dalam kehidupan sosial dilatarbelakangi oleh keinginan dalam diri sendiri untuk hidup berdampingan dengan orang lain, saling tolong menolong, memberi kebahagiaan dan kesejahteraan sehingga masing-masing orang dapat berfungsi dengan baik untuk kehidupan sosialnya. Penelitian Lara, dkk (2018) menyatakan bahwa Emosi positif dan feedback positif menggambarkan perhatian yang diberikan kepada seseorang sehingga dapat meningkatkan perilaku prososial. Jika diaplikasikan dalam penggunaan teknologi, akan sangat meminimalisir adanya kasus-kasus yang telah dijelaskan di atas. Karena masing-masing orang memiliki toleransi dan motivasi untuk membantu dan menghormati orang lain.

Perilaku prososial dapat ditingkatkan dengan berbagai cara. Di dunia pendidikan khususnya dimana kerjasama, toleransi dan karakter itu di bentuk, memiliki cara tersendiri yang dapat dilakukan oleh tenaga pendidik dan didukung oleh pihak-pihak terkait seperti staf dan orang tua siswa. Guru selaku pihak yang setiap hari bersinggungan langsung dengan siswa, memiliki kesempatan besar dalam membentuk perilaku prososial. Guru tidak harus bekerja sendiri untuk membentuk perilaku prososial tersebut namun dapat pula dibantu oleh konselor yang notabennya adalah pendamping perkembangan siswa secara optimal di sekolah. Terkait dengan peran guru dan konselor dalam membentuk perilaku prososial didahului oleh pembentukan komunikasi yang baik, penelitian Rene \& Nan (2005) menyatakan bahwa Sumber yang komunikatif yang didapatkan di lingkup pendidikan secara konsisten memiliki hubungan positif dengan perilaku prososial.

Terkait komunikasi pula, isi pesan dalam text tertentu dapat berpengaruh terhadap empati dan perilaku prososial seperti penelitian dari Sara, dkk (2015) yang hasilnya yakni Isi pesan yang membangun empati dapat meningkatkan afektif indikator dari empati dan perilaku prososial namun menurunkan self-perception dari empati yang relatif mengontrol pesan. Disini berarti dari pesan seseorang dapat dikontrol dalam memilih bahasa atau kalimat yang empatik.

Guru dan konselor dapat berkolaborasi untuk membentuk perilaku prososial siswa di sekolah dengan strategi-strategi tertentu yang disesuaikan dengan kegiatan yang dilakukan. Dengan strategi yang tepat diharapkan akan dapat meningkatkan perilaku prososial siswa sehingga tercipta iklim kerjasama, saling menghormati dan saling membantu antar siswa. Dengan demikian siswa akan lebih siap dalam menghadapi dan menyikapi perkembangan era teknologi dan informasi dengan bijak.

Penelitian-penelitian yang terkait dengan peningkatan perilaku prososial antara lain, penelitian Sebastian \& Michael (2010), yang menggunakan permainan musik untuk meningkatkan perilaku prososial pada anak, hasilnya bergabung dengan musik (bernyanyi dan menari) membuat perilaku prososial anak usia 4 tahun meningkat. Di dalam bermusik anak akan berinteraksi satu sama lain dengan cara yang sama di musikal, memiliki tujuan yang sama, berkoordinasi tentang tindakan mereka pada waktu itu, meniru gerakan dan komentar verbal 
satu sama lain, di dalam bermusik mereka juga berbagi emosi, pengalaman dan aktifitas bersama.

Selanjutnya penelitian dari Lusria \& Zulmi (2014) melalui kegiatan pramuka dapat meningkatkan perilaku prososial remaja di pondok pesantren. Selain di bidang ekstrakurikuler, guru bidang studi dapat pula meningkatkan perilaku prososial dalam pemberian tugas, seperti penelitian Singh \& Teoh (2014) bahwa perilaku prososial dapat ditingkatkan dengan menggunakan tugas abstrak daripada tugas konkrit. Elvirda (2016) juga meneliti tentang pengelolaan kelas dan dampaknya terhadap perilaku prososial, temuan penelitiannya yakni perilaku prososial anak-anak meningkat dalam bentuk perilaku kooperatif, persahabatan, membantu, berbagi, dan peduli.

Beberapa penelitian terkait strategi yang dapat dilakukan baik guru atau konselor untuk meningkatkan perilaku prososial antara lain, penelitian Nadav (2016) yang mengemukakan bahwa perilaku prososial dapat dirangsang melalui benefit psikologis, hal tersebut meningkatkan tindakan prososial. Benefit yang dimaksud dapat berupa reinforcement baik verbal maupun non verbal. Sejalan dengan penelitian Nadav, penelitian Lara \& Tanya (2015) menunjukkan hasil Reward emosional dalam tindakan untuk orang lain merupakan sesuatu yang lebih menguntungkan bagi seseorang daripada melakukan sesuatu untuk diri mereka sendiri. Reward emosional dapat berupa perasaan senang, puas, bahagia dan lain sebagainya.

Selain pemberian benefit dan reward psikologis strategi diskusi kelompok juga dapat meningkatkan perilaku prososial, seperti dalam penelitian Irsan, dkk. (2017) yang hasilnya menunjukan bahwa perilaku prososial siswa SMP Negeri 4 Palu sesudah mengikuti layanan diskusi kelompok lebih tinggi dibandingkan sebelum mengikuti layanan diskusi kelompok. Selain metode diskusi kelompok, penggunaan metode sosiodrama juga dapat meningkatkan perilaku prososial sesuai penelitian maria \& sinta (2014) yang hasilnya perilaku prososial siswa dapat ditingkatkan melalui layanan penguasaan konten dengan teknik sosiodrama.

Strategi yang bisa diterapkan khususnya guru BK menggunakan metode bimbingan kelompok juga dapat meningkatkan perilaku prososial, seperti penelitian Wulandari, dkk. (2018) yang hasilnya ada pengaruh yang signifikan penggunaan layanan bimbingan kelompok terhadap perilaku prososial siswa kelas vii.a SMP Negeri 22 Kota Bengkulu.

Dari hasil penelitian-penelitian di atas dapat disimpulkan bahwa perilaku prososial sangat diperlukan di era revolusi industri, dimana hampir semua orang tidak lepas dari yang namanya teknologi dan sangat berpengaruh terhadap kehidupan dan sebagian besar membuat individu tergantung. Dengan demikian tujuan penelitian ini adalah untuk mendeskripsikan bagaimana perilaku prososial siswa di era revolusi industri 4.0 dan upaya kolaborasi guru dan konselor dalam meningkatkan perilaku prososial siswa di sekolah. Agar tidak menghilangkan peran kehidupan sosial di era ini maka perilaku prososial perlu dikembangkan. Perilaku prososial dapat dikembangkan melalui berbagai strategi atau metode yang dapat diterapkan oleh guru mata pelajaran maupun guru BK. Kolaborasi antar keduanya diharapkan dapat menunjang terbentuknya atau meningkatnya perilaku prososial pada peserta didik sehingga peserta didik lebih siap secara fisik dan mental menghadapi era revolusi industri 4.0 tanpa terkena dampak negatif penggunaan teknologi khususnya pada aspek sosial-budayanya. 


\section{METODE}

Metode penelitian ini adalah deskriptif kualitatif. Cresswell (2012), menekankan bahwa penelitian kualitatif lebih mengeksplore masalah manusia dan sosial dalam seting yang natural dan holistik. Pemilihan deskriptif kualitatif didasarkan pada tujuan penelitian yang akan mendeskripsikan data mengenai perilaku prososial siswa di era revolusi industri 4.0 dan kolaborasi guru dan konselor dalam meningkatkan perilaku prososial siswa di sekolah.

Pemilihan subjek dalam penelitian ini menggunakan teknik purposive sampling yakni pemilihan sampel berdasarkan tujuan tertentu sesuai dengan tujuan penelitian dan kriteria yang diperlukan dalam penelitian (Creswell, 2012). Subjek dalam penelitian ini adalah konselor dengan beberapa kriteria diantaranya, konselor berada pada jenjang SMP/MTs di Kota Kediri, selanjutnya konselor harus berlatar belakang S1 BK, kemudian konselor harus memiliki kegiatan kolaboratif dengan guru/wali kelas.

Pengumpulan data dilakukan melalui beberapa cara antara lain observasi langsung, wawancara dan angket yang berisi pertanyaan terbuka melalui google dokumen. Kehadiran peneliti dalam penelitian ini tidak penuh, sebatas pada bentuk kegiatan pengamatan dan wawancara dengan konselor sekolah selebihnya untuk angket dikirim melalui email untuk diisi secara online.

Analisis data dilakukan dengan teknik naratif. Dan tahapan dalam analisis data mengadaptasi dari tahapan dari Miles \& Hubberman (dalam Yusuf, 2016) antara lain reduksi data, display data dan penarikan kesimpulan/verifikasi. Reduksi data menunjuk pada proses pemilihan, pemfokusan, penyederhanaan, pemisahan dan pentransformasian data mentah lapangan. Kemudian display data merupakan bentuk memaparkan data dalam bentuk narasi dan dalam bentuk display matrik. Display matrik menampilkan grafik atau tabel date termasuk kode untuk tujuan analisis (Miles \& Huberman \& Saldana, 2014). Selanjutnya penarikan kesimpulan yang didasarkan pada proses-proses analisis sebelumnya. Ketiga proses analisis data tersebut saling berhubungan satu sama lain.

\section{HASIL}

Dari hasil observasi, wawancara dan pelancaran angket pada beberapa konselor SMP/MTs di Kediri diperoleh berbagai informasi yang dikelompokkan dalam beberapa topik antara lain, penggunaan gadget oleh siswa di sekolah, interaksi siswa dengan guru dan interaksi siswa dengan siswa lain, dampak dari penggunaan gadget bagi siswa di sekolah, dan perilaku prososial siswa di sekolah.

Penggunaan gadget pada siswa di SMP/MTs tidak diperkenankan selama jam pelajaran sekolah kecuali pada matapelajaran dan materi tertentu yang membutuhkan bantuan internet misalnya matapelajaran TIK ataupun matapelajaran lain untuk praktik. Pada matapelajaran tertentu di sekolah tertentu ada matapelajaran khusus yang memerlukan browsing internet untuk mencari bahan pembelajaran, sehingga pada waktu tertentu siswa diperbolehkan untuk menggunakan handphone, namun setelah itu handphone harus disimpan kembali. Namun demikian, tidak jarang para guru menyita handphone siswa yang ketahuan membawa dan menggunakannya saat jam pelajaran berlangsung dan tidak pada waktu yang diperkenankan menggunakan handphone. 
Pada jenjang SMP ini rata-rata siswa memiliki sosial media dan aktif menggunakannya, bahkan antara guru dan siswa banyak yang saling terhubung di sosial media sehingga aktifitas siswa dapat dipantau melalui sosial media tersebut. Dengan adanya sosial media, bagi guru akan mempermudah dalam memperoleh informasi terkait dengan perkembangan-perkembangan terkini dan topik-topik yang sedang ramai dan menjadi bahan pembicaraan dikalangan siswa, guru juga mudah memperoleh informasi terkait dengan permasalahan yang dialami siswa.

Selanjutnya informasi yang didapat terkait dengan interaksi siswa dengan guru, dan siswa dengan siswa lain. Di beberapa SMP/MTs banyak guru yang mengeluhkan masalah etika dan sopan santun dari siswanya, banyak siswa kurang mampu menunjukkan sikap hormat pada guru bahkan cenderung meremehkan guru, hal tersebut dikarenakan siswa banyak mendapat role model dari sosial media maupun televisi, selain itu kedekatan yang dibangun antara guru dan siswa di sosial media membuat batasan peran masing-masing tidak terlihat lagi. Guru bukan lagi menjadi sosok yang dihormati namun banyak siswa yang menganggap guru seperti teman yang dalam berinteraksi tidak perlu menggunakan norma-norma sosial pada umumnya.

Selanjutnya interaksi siswa dengan siswa lain, adanya era disrupsi ini membuat peran orang lain di sekitar cenderung tergantikan dan fokus pada siswa menjadi bebada tidak sesuai dengan yang semestinya. Beberapa fenomena yang diamati dan hasil wawancara dengan konselor, banyak siswa yang mengalami perubahan terhadap kepedulian lingkungan ini, hal ini sering dibuktikan dengan sikap acuh terhadap lingkungan, ketika seseorang mendapatkan role model dari sosial media, mereka cenderung membentuk kelompok yang sesuai dengan minat dan mengesampingkan kelompok lain yang dianggap tidak sesuai, perilaku yang muncul kadang terjadi bullying dan perilaku agresif baik secara lisan maupun fisik.

Selain itu, banyak siswa yang mengutamakan eksistensi di dunia maya daripada eksistensi di dunia nyata dan cenderung mengesampingkan tugas utamanya sebagai seorang pelajar. Dampaknya, banyak siswa SMP dan sederajat yang tugas perkembangannya terkadang tidak sesuai dengan tahapannya. Misalnya, pada perkembangan psikososial siswa SMP yang masih berada pada tahap mencari identitas melompat ke tahap selanjutnya yakni intimacy (membangun hubungan dekat dengan lawan jenis seperti orang dewasa).

Perilaku sosial lain yang dapat diamati khsusunya melalui sosial media siswa SMP, mereka cenderung mengungkapkan simpati, empati dan emosi terhadap orang lain menggunakan bahasa tertulis dan terbuka sesuai dengan isi hati mereka, bukan mengungkapkan secara langsung, padahal ketika bertemu atau tatap muka terkadang tidak ada percakapan yang berarti. Hal ini menunjukkan bahwa interaksi langsung antar individu mulai memudar. Perilaku lain yang sering ditunjukkan oleh para siswa ketika para siswa berkumpul dalam suatu kegiatan, mereka lebih tertarik berinteraksi dengan gadget daripada berinteraksi dengan ligkungan sekitarnya (pengamatan di luar konteks sekolah).

Dari fenomena-fenomena tersebut, guru dan konselor beserta civitas akademik yang lain memiliki peran besar dalam membantu anak menyiapkan diri memasuki era IR-4. Hal ini dapat dilakukan dengan cara meningkatkan ketrampilan lain diluar kemampuan akademik yang dimiliki. Guru di era IR-4 bukan hanya sebagai penyampai informasi kepada siswa, namun juga sebagai role model dalam pengembangan sikap, ketrampilan dan perilaku. Sehingga 
diharapkan nantinya siswa tidak hanya cerdas secara akademik namun juga mampu bersikap bijak, mampu berinovasi dan mengembangkan kreatifitasnya sesuai dengan tuntutan zaman. Pola interaksi dengan lingkungan perlu dibentuk agar siswa tidak kehilangan jati dirinya sebagai makhluk sosial. Jika semua hal sudah tergantikan oleh teknologi, hendaknya peran lingkungan sosial tetap terjaga demi mendukung perkembangan sosialnya secara optimal.

Perilaku dalam menggunakan gadget di sekolah memang tidak dapat diamati secara langsung karena adanya peraturan yang berlaku, namun dampak dari hal tersebut terlihat melalui perilaku, sikap / etika, dan gaya komunikasi ketika dengan guru ataupun dengan temanteman mereka. Dibawah ini merupakan gambaran sikap dan perilaku siswa SMP terkait dampak dari penggunaan gadget.

Tabel 1.1 Dampak Penggunaan Gadget pada Siswa SMP

\begin{tabular}{|c|c|c|}
\hline \multirow[t]{2}{*}{ Aspek } & \multicolumn{2}{|r|}{ Dampak } \\
\hline & Positif & Negatif \\
\hline Perilaku & $\begin{array}{l}\text { - Mempermu-dah dalam } \\
\text { mengakses berbagai hal } \\
\text { terkait pembelajaran } \\
\text { - Memper-mudah dalam } \\
\text { mendapatkan informasi dan } \\
\text { referensi untuk mendukung } \\
\text { kegiatan belajar } \\
\text { - Kemahiran dalam mencoba } \\
\text { berbagai aplikasi yang } \\
\text { memper-mudah dalam } \\
\text { memperoleh informasi atau } \\
\text { pengetahuan } \\
\text { - Memperluas hubungan } \\
\text { multilateral dengan } \\
\text { menggunakan sosial media }\end{array}$ & $\begin{array}{l}\text { - Kecanduan game online } \\
\text { - Mengakses hal-hal yang tidak bermanfaat } \\
\text { dan terlarang } \\
\text { - Minimnya komunikasi aktif siswa terhadap } \\
\text { ligkungan sosial } \\
\text { - Menggunakan kata-kata yang kurang } \\
\text { pantas di sosial media } \\
\text { - Bullying } \\
\text { - Agresifitas } \\
\text { - Menjadi pribadi yang konsumtif } \\
\text { - Malas beraktifitas } \\
\text { - kepedulian sosial yang kurang dan makin } \\
\text { dikesampingkannya norma sosial } \\
\text { - }\end{array}$ \\
\hline $\begin{array}{l}\text { Sikap/ } \\
\text { etika }\end{array}$ & $\begin{array}{l}\text { - Menumbuh-kan kreatifitas, } \\
\text { motivasi bersaing yang } \\
\text { tinggi, mengembangkan } \\
\text { kreatifitas } \\
\text { - Siswa dapat mengikuti } \\
\text { perkembangan jaman } \\
\text { dengan cepat } \\
\text { - Mengembangkan pola pikir } \\
\text { anak }\end{array}$ & $\begin{array}{l}\text { - Kurang menghargai orang lain yang } \\
\text { ditunjukkan dengan komentar-komentar } \\
\text { negatif di sosial media } \\
\text { - Bebas meluapkan emosi negatif terhadap } \\
\text { orang lain } \\
\text { - Menurunnya minat belajar siswa akibat } \\
\text { kecanduan gadget } \\
\text { - Memudarnya rasa simpati, empati dan } \\
\text { toleransi akibat dari kebutuhan individu } \\
\text { untuk eksistensi di sosial media }\end{array}$ \\
\hline $\begin{array}{l}\text { Gaya } \\
\text { komuni- } \\
\text { kasi }\end{array}$ & $\begin{array}{l}\text { - Memperkaya perbenda- } \\
\text { haraan kata/istilah baru } \\
\text { - Memperlancar komunikasi } \\
\text { antar individu }\end{array}$ & $\begin{array}{l}\text { - Bebas berkomentar dengan kata-kata yang } \\
\text { kurang pantas } \\
\text { - Kurang memperhatikan norma dalam } \\
\text { berbicara dengan orang yang lebih tua } \\
\text { - Memunculkan istilah-istilah baru yang tidak } \\
\text { baku dan sulit dimengerti orang awam }\end{array}$ \\
\hline
\end{tabular}


Hasil pengumpulan data terkait dengan perilaku prososial siswa SMP/MTS yang dapat diamati, banyak siswa yang cenderung berkelompok atau membuat grup dan dalam kelompok tersebut rata-rata mereka memiliki minat yang sama terhadap sesuatu entah itu gaya hidup, hobi dan lain-lain. Sebagian besar siswa memiliki tokoh idola entah tokoh film, tokoh dari sosial media seperti instagram, facebook, youtube dan lain-lain yang membuat perilaku, sikap, gaya komunikasi mereka mengikuti tokoh idolanya. Permasalahan terkait perilaku sosial siswa SMP sebagian besar ditimbulkan karena masalah kecanduan gadget dan kecanduan sosial media demi eksistensi.

Siswa kecanduan gadget misalnya kecanduan game online dan kecanduan dalam berselancar di dunia maya, menunjukan sikap apatis terhadap lingkungan. Dampak yang ditimbulkan bagi siswa yang mengalami hal itu antara lain mereka hanya bersikap dan berperilaku sekedarnya di lingkungan sosial, kurang peka dan kurang cepat tanggap dengan fenomena di sekitar, dan cenderung memikirkan hal yang menguntungkan diri sendiri.

Selanjutnya siswa yang kecanduan sosial media selalu ingin eksis baik di dunia maya maupun di dunia nyata, mereka cenderung tidak mempedulikan lingkungan sekitar dan juga mengesampingkan norma sosial yang ada. Siswa cenderung berupaya maksimal untuk mewujudkan eksistensinya tersebut meskipun kadang cara yang digunakan menuai pro dan kontra dari lingkungan. Sebagai contoh, seorang siswa yang selalu ingin eksis di sosial media dengan mengeluarkan pernyataan-pernyataan yang kontrovesrsial dan memicu konflik, menulis kata-kata yang tidak sopan, membuly orang lain dan sebagainya.

Demikian paparan mengenai perilaku prososial siswa remaja di era revolusi industri 4.0. Selanjutnya berkaitan dengan upaya guru dan konselor dalam meningkatkan perilaku prososial siswa yang dilakukan melalui berbagai kegiatan. Dari hasil pelancaran angket dan wawancara diperoleh data yang berkaitan dengan bentuk kolaborasi atau kegiatan yang dapat dilakukan guru dan konselor dalam meningkatkan perilaku prososial dijabarkan dalam tabel berikut:

\section{Tabel 1.2 kolaborasi guru dan konselor}

\begin{tabular}{|c|c|c|}
\hline \multirow[t]{2}{*}{ Kegiatan } & \multicolumn{2}{|c|}{ Pelaksana } \\
\hline & Konselor & Guru \\
\hline Pelatihan yang berkaitan dengan meningkatkan ketrampilan sosial & $\sqrt{ }$ & $\sqrt{ }$ \\
\hline Konseling sebaya & $\sqrt{ }$ & \\
\hline $\begin{array}{l}\text { pemberian tugas yang sistematis dan melibatkan individu satu dengan yang } \\
\text { lain }\end{array}$ & & $\sqrt{ }$ \\
\hline $\begin{array}{l}\text { Berkegiatan di luar kelas dengan melakukan permainan-permainan } \\
\text { kooperatif }\end{array}$ & & $\sqrt{ }$ \\
\hline Membuat proyek penemuan-penemuan spektakuler bersama siswa & & $\sqrt{ }$ \\
\hline Diskusi kelompok, problem solving, dan petualangan bersama. & $\sqrt{ }$ & $\sqrt{ }$ \\
\hline Parenting class bersama-sama dengan konselor & $\sqrt{ }$ & $\sqrt{ }$ \\
\hline $\begin{array}{l}\text { Melakukan modeling ketika proses pembelajaran maupun diluar proses } \\
\text { pembelajaran }\end{array}$ & $\sqrt{ }$ & $\sqrt{ }$ \\
\hline pemberian informasi dan pembiasaan & $\sqrt{ }$ & $\sqrt{ }$ \\
\hline
\end{tabular}

Dari tabel diatas dapat disimpulkan bahwa konselor melakukan upaya kolaborasi dengan guru melalui kegiatan-kegitan pengembangan soft skill siswa dan juga pemberian 
layanan informasi. Namun yang terkait aktifitas pengembangan dalam kegiatan-kegiatan pembelajaran dilakukan oleh guru.

\section{PEMBAHASAN}

Penelitian ini bertujuan untuk mendeskripsikan mengenai perilaku prososial di era revolusi industri 4.0 (IR-4) dan upaya kolaborasi guru dan konselor dalam mengembangkan perilaku prososial. Dari hasil penelitian dapat diketahui bahwa perilaku prososial siswa usia remaja awal pada khususnya, saat ini banyak mengalami penurunan, hal ini diakibatkan karena perubahan-perubahan yang timbul di era IR-4 yang berpengaruh pada pola pikir, sikap dan perilaku siswa. Beberapa pembahasan terkait hasil penelitian akan dijabarkan sebagai berikut:

\section{Perilaku Prososial Siswa SMP di Era Revolusi Industri 4.0}

Demi eksistensi seseorang cenderung mencari teman yang memiliki minat yang sama dan cenderung mengikuti aturan kelompok baik disukai maupun tidak disukai. Hal ini sesuai dengan teori psikososial Erickson (1995), bahwa pada masa remaja dimana seorang anak mencari identitas diri akan rela bergabung dalam kelompok meskipun tidak merasa nyaman, membuat stereotip kelompok, membuat sesuatu yg ideal dalam kelompok, menetapkan siapa musuh dan kadang menguji anggota lain tanpa alasan untuk membuat suatu janji sebagai bentuk kesetiaan dalam kelompok.

Perubahan besar pada revolusi industri 4.0 membuat manusia semakin tergantung dengan kecanggihan teknologi dan menuntut manusia untuk dengan cepat beradaptasi. Dalam dimensi intelektualitas, kemajuan teknologi memiliki kontribusi penting dalam pencarian informasi, pengolahan informasi dan penciptaan sesuatu yang baru berdasarkan teknologi. Namun disisi lain, keberadaan manusia di lingkungan sosial menjadi kurang bermakna. Dengan kata lain, peran manusia lain sudah tergantikan oleh mesin yang canggih yang dibutuhkan oleh masing-masing orang. Hal tersebut dapat berdampak pada sikap individualis, kurangnya toleransi sesama, dan minimnya rasa hormat serta keinginan untuk saling tolong menolong. Padahal, Manusia dan kehidupan sosial menjadi kunci pokok yang memiliki kontribusi penting dalam berbagai hal misalnya tingginya tingkat pendapatan, kepuasan hidup, dan kohesi sosial (Healy \& Cote, 2001).

Untuk dapat beradaptasi dengan perubahan besar yang terjadi saat ini khususnya perubahan dalam hierarki sosial, mengembalikan fitrah manusia sebagai makhluk sosial perlu dilakukan terutama dengan mengembangkan perilaku prososial. Pengembangan perilaku prososial perlu dilakukan untuk mengembalikan fungsi individu sebagai makhluk sosial yang dapat berinteraksi dengan lingkungan tanpa selalu menggunakan media, dengan kata lain interaksi fisik secara langsung (face to face) dengan memperhatikan eksistensi masing-masing. Selain itu perilaku prososial perlu dibentuk untuk menumbuhkan toleransi yang saat ini sudah mulai memudar. Dari hasil kuesioner, beberapa perilaku prososial yang perlu dikembangkan antara lain, toleransi, peduli antara sesama, sikap peka/tanggap/sigap dengan sekitar, sikap yang tidak individualis, tanggung jawab, kerjasama, respect, altruis, empati, gotong royong, saling menghormati, kepedulian, kesopanan baik dalam tutur kata maupun sikap dan tata krama baik di lingkungan rumah, sekolah, masyarakat. Selanjutnya sikap hormat kepada yang lebih tua, simpati, dan empati. 
Bentuk-bentuk perilaku prososial di atas dapat dibentuk dalam diri siswa dengan menggunakan strategi-strategi tertentu. Strategi-strategi tersebut bisa diterapkan oleh tenaga pengajar dalam hal ini guru yang bertatap muka langsung dengan siswa, dan juga konselor sebagai pembimbing siswa dalam mencapai perkembangan optimal. Kolaborasi antar keduanya diharapkan dapat mengoptimalkan pengembangan perilaku prososial peserta didik.

Revolusi industri 4.0 merupakan era disrupsi yang menimbulkan banyak perubahan di segala aspek. Perubahan tersebut terkait dengan pola pikir, sikap dan perilaku, dan yang paling kentara adalah terkait dengan cara kita merencanakan, melakukan ataupun menghasilkan sesuatu.

Menelaah perubahan-perubahan dari revolusi industri pertama. Robert (2015) mengemukakan beberapa penjelasan terkait tahap-tahap revolusi industri dari yang pertama. Revolusi industri pertama dan kedua merupakan kekuatan yang mendorong pembentukan masyarakat modern. Revolusi-revolusi tersebut menghasilkan perubahan signifikan dalam ideologi, hierarki sosial, manufaktur dan distribusi, hubungan internasional, hubungan perdagangan, dan yang paling penting, kemajuan teknologi. Berbeda dengan dua revolusi industri sebelumnya, revolusi industri ketiga juga memiliki efek signifikan dalam mengubah hampir setiap aspek dalam masyarakat, terutama dalam cara hidup dan merencanakan sesuatu. Hal ini dikarenakan pada revolusi industri ketiga sudah dikembangkan sistem otomastisasi, listrik dan komputerisasi. Revolusi industri ketiga berdampak besar dalam bidang TIK, pengetahuan, pertahanan, kesehatan, pendidikahmbn, manufaktur, sektor keuangan dan administrasi. Dalam bidang pendidikan khususnya pemanfaatan teknologi di era ini masih dalam kategori moderat/sedang, khususnya dalam hal produksi teknologi, menciptakan keuntungan, energi, material, pengetahuan, informasi, pemakaian, pengelolaan, dan perubahan sosial. Hanya dalam hal kreatifitas dalam dunia pendidikan masuk kategori tinggi.

Selanjutnya aspek-aspek perubahan pada revolusi industri keempat khususnya dalam bidang pendidikan antara lain, inovasi pendidikan 4.0. IR-4 dikendalikan oleh kecerdasan buatan dan kerangka kerja fisik digital yang membuat mesin penghubung manusia yang lebih universal. Revolusi cepat dalam inovasi telah menghasilkan model pendidikan lain untuk masa depan yakni Pendidikan 4.0. Untuk mempersiapkan lulusan masa depan dan pekerjaan yang akan dicapai dalam IR-4 di mana lebih banyak robot pintar yang akan menggantikan orangorang di divisi kegiatan tertentu, pendidikan harus memanfaatkan informasi dan kemampuan terkait yang tidak dapat digantikan oleh robot (Shahroom \& Norhayati, 2018). Dengan kata lain, peserta didik dipersiapkan untuk menjadi siswa yang cerdas dan mampu menghadapi era disrupsi yang mana ketrampilan yang dimiliki nantinya tidak dapat bertahan dan tidak tergantikan oleh mesin robotik.

Dalam dunia pendidikan, adanya IR-4 tidak hanya merubah tata cara dalam mengorganisir sebuah lembaga pendidikan, ataupun merubah tata cara guru dalam mengelola pembelajaran, namun juga merubah beberapa aspek dalam diri siswa. Dari hasil angket yang dilancarkan peneliti, menunjukkan adanya beberapa perubahan pada diri siswa dalam era IR4 , khususnya dampak dari pemanfaatan teknologi itu sendiri. 


\section{Bentuk Kolaborasi Guru dan Konselor dalam Meningkatkan Perilaku Prososial di Era Revolusi Industri 4.0}

Dalam lingkup pendidikan, peran pendidik sangat penting dalam mengembangkan konsep diri dan aspek sosial siswa. Seorang siswa yang mengalami keberhasilan akademik di kelas ditentukan oleh keberhasilan dalam perkembangan sosial mereka (Lavoie, 2019). Dalam mengembangkan ketrampilan sosial tidak selalu dapat dilakukan ketika proses pembelajaran di kelas, oleh karena itu diperlukan kolaborasi dengan konselor yang memiliki kompetensi terkait perkembangan anak untuk membentuk kegiatan diluar proses pembelajaran di kelas, untuk mengembangkan aspek sosial khususnya perilaku prososial siswa.

Kegiatan-kegiatan yang dilakukan bersama antara konselor dengan guru matapelajaran tersebut di atas bertujuan untuk, pertama selain memaksimalkan kemampuan akademik juga mengoptimalkan kemampuan nonakademik siswa khsusunya dalam perkembangan aspek sosialnya, kedua mengoptimalkan kemampuan guru dan konselor dalam membimbing siswa agar dapat beradaptasi dengan baik di era digital dan meminimalisir dampak negatif yang ditimbulkan.

Pertimbangan kolaborasi tersebut antara lain, guru sebagai tenaga pengajar yang selalu bertatap muka dengan siswa asumsinya mengenal dengan baik siswa yang diajar dan mampu mengajar serta mendidik siswa siswinya. Selanjutnya, konselor yang ahli dalam bidang bimbingan yang berfokus pada perkembangan siswa asumsinya dapat memahami cara membimbing dan mengarahkan siswa agar mencapai perkembangan optimal dengan menggunakan strategi-strategi tertentu.

Disamping kolaborasi dengan guru, dalam modul pelaksanaan kurikulum 2013 (kemendikbud, 2013) ditekankan perlunya kolaborasi antara guru BK atau konselor dengan personil sekolah lain seperti kepala sekolah, staf administrasi, orang tua dan pihak terkait lainnya. Pendekatan terintegrasi ini bertujuan untuk membantu peserta didik agar dapat mengembangkan atau mewujudkan potensi dirinya secara utuh, baik aspek pribadi, sosial, belajar dan karir atau terkait dengan pengembangan pribadi peserta didik sebagai makhluk yang berdimensi biopsikososiospiritual (biologis, psikis, sosial, spiritual).

Kolaborasi yang dilakukan baik oleh konselor dengan guru ataupun personel sekolah yang lain, diharapkan dapat membantu siswa dalam meningkatkan pemahaman diri sendiri, orang lain / lingkungan dan dalam pengambilan keputusan terutama dalam bersikap dan berperilaku menghadapi era disruptif saat ini.

\section{KESIMPULAN DAN SARAN}

Penelitian ini menunjukkan hasil bahwa perilaku prososial siswa remaja di era revolusi industri 4.0 semakin menurun, hal tersebut dikarenakan perubahan-perubahan yang terjadi dan berpengaruh terhadap pola pikir, sikap, dan perilaku siswa. Untuk mengembalikan fitrah individu sebagai makhluk sosial maka terdapat upaya yang dilakukan oleh guru dan konselor melalui kolaborasi dalam mengembangkan perilaku prososial siswa dalam berbagai bentuk kegiatan pengembangan di sekolah. Untuk peneliti selanjutnya, disarankan untuk lebih mendalami tentang dampak-dampak lain yang muncul akibat era revolusi 4.0 , khususnya dampak pada di 
dunia pendidikan. Selanjutnya, mengembangkan sebuah instrumen yang bisa digunakan sebagai acuan untuk cerdas dalam berteknologi menyesuaikan era yang ada.

\section{DAFTAR RUJUKAN}

Aida aryani shahroom and norhayati hussin, "industrial revolution 4.0 and education," international journal of academic research in business and social sciences 8, no. 9 (2018): 22-24, https://doi.org/10.6007/ijarbss/v8-i9/4593.

Aknin, lara b., tanya broesch. Prosocial behavior leads to happiness in a small-scale rural society journal of experimental psychology: general american psychological association 2015, vol. 144, no. 4, 788-795

Andreja, rojko. Industry 4.0 concept: background and overview. Ijim 77 - vol. 11, no. 5, 2017, diakses 15 Desember 2018

Andy cerika \& sinan maksumic. The effects of new emerging technologies on human resources: emergence of industry 4.0 , a necessary evil?. Article (university of agder, 2017)

Bekkers, rené and nan dirk de graaf. Field of education and prosocial behavior. Article. Aper prepared for marktdag sociologie, june 2, 2005, Brussels

Cresswell, J. W. (2012). Educational Research (4th ed.). New York: Pearson.

Deepty gupta, geeta thapliya. A study of prosocial behaviour and self concept of adolescents $i$ manager's journal on educational psychology, vol. 9 I no. 1 may - july 2015

Hartanti, Maria T.S. \& Sinta Saraswati. Meningkatkan Perilaku Prososial Rendah Melalui Layanan Penguasaan Konten dengan Teknik Sosiodrama. Indonesian Journal of Guidance and Counseling: Theory and Aplication Vol.3 No.3 (2014)

Healy, T., \& Cote, S. (2001). The Well-Being of Nations: The Role of Human and Social Capital Education and Skills. Organization for Economic Cooperation and Development. Organisation for Economic Co-operation and Development.

Irsan, abdul munir, munifah. Pengaruh layanan diskusi kelompok terhadap peningkatan perilaku prososial siswa (studi kasus di smp negeri 4 palu). Jurnal konseling \& psikoedukasi volume 2, nomor 1, juni 2017. Hal. $29-44$

Josina. Kasus Pelecehan Online, Aplikasi Facebook \& Whatsapp Tertinggi, Artikel, https://inet.detik.com/cyberlife/D-4371682/kasus-pelecehan-online-aplikasifacebook-whatsapp-tertinggi, (diakses, 15 desember 2018)Larasati, Citra. Cyber Bullying di Kalangan Siswa Meningkat di 2018. Artikel. http://news.metrotvnews.com/peristiwa/dkqq49ek-cyber-bullying-di-kalangan-siswameningkat-di-2018 (diakses 15 desember 2018)

Kirschner, sebastian \& michael tomasello. Joint music making promotes prosocial behavior in 4-year-old children. Journal of evolution and human behavior 31 (2010) 354 - 364 
Konrath, sara., emily falk, andrea fuhrel-forbis, mary liu, james swain, richard tolman, rebecca cunningham, maureen walton. Can text messages increase empathy and prosocial behavior?. Article. Plos one | doi:10.1371/journal.pone.0137585 september 10, 2015

Lara b aknin1, julia w van de vondervoort2 and j kiley hamlin. Positive feelings reward and promote prosocial behavior. Journal of current opinion in psychology 2018, 20:55-59

Lavoie, rick, "the teacher's role in developing social skills | Id topics | Id online," accessed march 4, 2019, http://www.Idonline.org/article/6170/.

Lusiria, devi, zulmi yusra. Efektivitas pelatihan pramuka peduli untuk meningkatkan perilaku prososial remaja di pondok pesantren. Jurnal riset aktual psikologi vol.5 no.1 2014

Matondang, elvrida sandra. Perilaku prososial (prosocial behavior) anak usia dini dan pengelolaan kelas melalui pengelompokan usia rangkap (multiage grouping). Jurnal pendidikan dasar vol. 8. No.1, januari 2016 hal 34-47

Nadav, klein. Prosocial behavior increases perceptions of meaning in life. The journal of positive psychology, june 2016

Nugraha mega. Kejahatan di dunia maya meningkat, tahun 2018 polda jabar tangani 288 kasus, http://jabar.tribunnews.com/2018/12/28/kejahatan-di-dunia-maya-meningkat-tahun2018-polda-jabar-tangani-288-kasus, (diakses 15 desember 2018)

Puspita, ratna. Menristekdikti: revolusi industri 4.0 harus dibarengi perubahan perilaku. Https://republika.co.id/berita/pendidikan/dunia-kampus/18/12/03/pj5he4428menristekdikti-revolusi-40-harus-dibarengi-ubah-perilaku, (diakses 15 desember 2018)

Roberts, "the third industrial revolution: implications for planning cities and regions."

Seli andina miranti, cinta ditolak, bocah ini bunuh gadis yang dikenalnya di dunia maya, http://jabar.tribunnews.com/2018/10/23/cinta-ditolak-bocah-ini-bunuh-gadis-yangdikenalnya-di-dunia-maya, (diakses 15 desember 2018)

Singh, s., \& teoh, v.y. Enhancing prosocial behavior among college students: exploring the role of abstract mindset. International journal of law and social sciences, 3, 2 (2014)

Sukoyo, Yeremia. Penyimpangan Penggunaan TI akan Mendistorsi Kehidupan Masyarakat, artikel, https://www.beritasatu.com/nasional/525707-penyimpangan-penggunaan-Tlakan-mendistorsi-kehidupan-masyarakat.html, (diakses 15 desember 2018)

Wulandari tri, i wayan dharmayana, vira afriyati. Pengaruh layanan bimbingan kelompok terhadap perilaku prososial siswa kelas vii di smp negeri 22 kota bengkulu. Jurnal ilmiah bimbingan dan konseling, volume 1 nomor 22018

Xing bo and tshilidzi marwala, "implications of the fourth industrial age on higher education," accessed february 24, 2019, https://arxiv.org/ftp/arxiv/papers/1703/1703.09643.pdf. 